\title{
Serum Total Bilirubin and Aminotransferases in Patients with COVID-19 in Nellore District of South Andhra Pradesh
}

\author{
Kiranmayi Bogarapu ${ }^{1}$ \\ ${ }^{1}$ Department of Biochemistry, ACSR Government Medical College and Hospital, \\ Dargamitta, Nellore, Andhra Pradesh, India.
}

\section{ABSTRACT}

\section{BACKGROUND}

Corona virus disease - 19 (COVID -19) infection is an acute infectious disease caused by a newly discovered beta corona virus, severe acute respiratory syndrome corona virus 2 (SARS-CoV-2). While the primary target organ is the lungs, involvement of many other organs is often evident in patients with COVID - 19. There is emerging evidence to suggest association of SARS-CoV-2 infection with development of many liver abnormalities. The purpose of this study was to evaluate the prevalence of abnormal liver parameters in COVID - 19 patients and their variation in moderate and severe cases.

\section{METHODS}

This is a retrospective study. All patients with COVID -19, between the ages 20 - 75 years, encountered between April and May 2021, were included for the study and compared with age-matched controls. Severity of infection was defined based on the presence of symptoms, oxygen saturation, need for respiratory and intensive care support. Liver parameters such as serum total bilirubin (TBIL), serum aminotransferases, alanine aminotransaminase (ALT) and aspartate aminotransaminase (AST) were analysed. Inflammatory markers such as C-reactive protein (CRP) and D-dimer were also included for assay.

\section{RESULTS}

A total of 52 patients were encountered during the study period. Of these, $29 \%$ $(15 / 52)$ required intensive care. Abnormal liver parameters were observed in 14 (27\%) patients, and were significantly elevated compared to healthy controls. Liver dysfunction was markedly profound in severe infection than those with moderate disease. Higher levels of CRP and D-dimer were noted in severe patients of COVID 19.

\section{CONCLUSIONS}

Mild liver abnormalities in the form of elevated ALT and AST are seen in COVID - 19 patients suggesting mild or no liver injury. These abnormal parameters do not generally lead to significant liver function impairment/failure and no specific treatment is required.

\section{KEY WORDS}

COVID - 19, Corona Virus, Liver Injury, Intensive Care Support.
Corresponding Author: Dr. Kiranmayi Bogarapu, Associate Professor, Department of Biochemistry, ACSR Government Medical College, Dargamitta, Nellore, Andhra Pradesh, India. E-mail: kiranmayibogarapu@gmail.com

DOI: $10.14260 /$ jemds/2021/793

How to Cite This Article:

Bogarapu K. Serum total bilirubin and aminotransferases in patients with COVID19 in Nellore district of South Andhra Pradesh. J Evolution Med Dent Sci 2021;10(45):3925-3930, DOI: 10.14260/jemds/2021/793

Submission 05-11-2021, Peer Review 12-11-2021, Acceptance 10-12-2021, Published 28-12-2021.

Copyright (C) 2021 Kiranmayi Bogarapu et al. This is an open access article distributed under Creative Commons Attribution License [Attribution 4.0 International (CC $B Y 4.0)]$ 


\section{BACKGROUND}

Corona virus disease 2019 (COVID - 19) is an acute infectious respiratory disease caused by the novel severe acute respiratory syndrome corona virus 2 (SARS-CoV-2). Being highly contagious, COVID-19 has panned across the world causing millions of deaths the world over. ${ }^{1}$ As SARS-CoV-2 has spread, it has evolved and developed mutations, causing new variants of the disease. ${ }^{2}$ Due to the emerging new variants that may possess enhanced virulence, viral transmissibility, re-infection rates and disease severity; it has become a concern of health emergency. The second peak of COVID - 19 pandemic had struck India hard with daily cases and deaths at more than 400,000 cases and 4000 deaths respectively. Clinical presentation of COVID - 19 is varied, ranging from asymptomatic to a severe infection characterized by multisystem organ failure. High risk population includes persons with co-morbidities like diabetes, hypertension, heart disease, malignancy and advanced age who can develop more severe disease, typically over the second week of the disease, associated with respiratory compromise, coagulopathy, multi-organ failure, and death. Oxygen supplementation, invasive ventilation and other support measures now form part of the standard of care in hospitalized patients, however mortality remains high among those with critical disease. ${ }^{1}$

Lungs have been recognized as the primary target organs for COVID - 19. However, patients with COVID - 19 frequently show evidence of damage to other organs such as gastrointestinal tract, liver and other organs. Pathophysiology of the multi-organ damage in COVID - 19 is multifactorial and may be associated with organ-specific immune response to disseminated corona virus or secondary to hypoxemia, systemic cytokine storm, and medication. Direct or indirect damage from SARS-Cov-2 itself, to liver tissue, through the generated multisystem inflammation is postulated as the key inciting agent, especially in most severe stages. ${ }^{3}$ Medications used for COVID - 19 such as antibiotics, corticosteroids and antiviral drugs are all potentially hepatotoxic. Acetaminophen used for COVID - 19 symptom relief and can cause alterations in aminotransferases even at therapeutic doses. ${ }^{4,5}$ Anticoagulant usage in severe patients is a well-known cause of the potential risk of drug induced liver damage (DILI).3,6 Previous studies have reported the prevalence of abnormal liver function tests in patients with COVID - 19, primarily alanine aminotransferase (12.9-41.6 $\%)$ and aspartate aminotransferase (18.2 - $66.9 \%) .^{7-10}$ However, there are limited studies looking into the trends of South Indian population.

\section{Objectives}

We conducted a retrospective study to determine the liver parameters in COVID - 19 infection in Nellore district of South Andhra Pradesh. Liver parameters such as serum total bilirubin, alanine aminotransferase \& aspartate aminotransferase in COVID - 19 patients, during the second peak of the disease, were analysed and compared with healthy controls. Inflammatory markers like C - reactive protein and D-dimer were also evaluated in order to access the severity of the disease.

\section{METHODS}

The retrospective study was done on patients admitted with the diagnosis of COVID - 19 in Government General Hospital, ACSR Government Medical College, Nellore between April and May 2021. After Institutional review board approval, medical records were reviewed for demographics, severity of illness, oxygen saturation and the treatment received during hospitalization. All COVID - 19 patients between ages 20 - 75 years were included in the study. All patients were during the second week of illness. Thirty age-matched healthy patients served as controls. Patients with chronic liver disorders, alcoholism, any pre-existing chronic conditions especially associated with low oxygen saturations, immunodeficiency, cancer, on immunosuppressant therapy were excluded from the study.

The diagnosis of COVID - 19 was made using the "gold standard" reverse transcription polymerase chain reaction (RT-PCR) from nasopharyngeal swabs. Severity was categorized as mild, moderate and severe, based on the presence of symptoms, oxygen saturation and need for respiratory support either in the form of nasal cannula or mechanical ventilation. Patients with fever, uncomplicated upper respiratory tract infection with $\mathrm{SpO}_{2}>94 \%$ were defined as mild cases while moderate cases were defined as any patient meeting any of the following criteria: 1) respiratory rate $\geq 24$ breaths/minute, 2) $\mathrm{SpO}_{2}<94 \%$ at rest 3) need for respiratory support in any form, such as nasal cannula or mechanical ventilation. Severe cases had criteria of 1) Respiratory rate $\geq 30$ breaths/minute 2) $\mathrm{SpO}_{2}<90 \%$ 3) chest CT showing increased CO-RAD that required intensive care unit. Moderate and severe cases were taken into account as mild cases were advised home quarantine. All patients in the severe category received treatment with antibiotics, corticosteroids, and antivirals especially remdesivir.

Blood samples were collected under strict aseptic conditions into plain vacutainers and the serum was separated by centrifugation. Serum total bilirubin, alanine aminotransferase, aspartate aminotransferase and C-reactive protein were analysed using ERBACHEM-7 analyser. Estimation of total bilirubin was by Diazo method, and IFCC kinetic method was used for analysis of serum aminotransaminases, ALT and AST. C-reactive protein and Ddimer was estimated by quantitative turbidimetric method.

In the Diazo method of Pearlman and Lee, ${ }^{11}$ bilirubin reacts with diazotized sulphanilic acid in acidic medium to form pink coloured azobilirubin whose absorbance is directly proportional to the bilirubin concentration. Direct or conjugated bilirubin being water soluble directly reacts in acidic medium. However indirect/unconjugated bilirubin is solubilised by a surfactant and then it reacts similar to direct bilirubin.

In the International federation of clinical chemistry (IFCC) kinetic method for serum aminotransaminases, alanine aminotransferase and aspartate aminotransferase, ALT in serum catalyses the transamination reaction between its substrates, L-alanine and $\alpha$-ketoglutarate yielding Lglutamate and pyruvate. Similarly, AST in serum catalyses the transamination reaction between its substrates, L-aspartate and $\alpha$-ketoglutarate yielding L-glutamate and oxaloacetate. Oxaloacetate is spontaneously decarboxylated to pyruvate. 
The pyruvate so produced by transamination reacts with NADH to form NAD and L-Lactate which is measured.

The C-reactive protein in human serum or plasma is measured by CRP- Turbilatex, ${ }^{12}$ a quantitative turbidimetric test. The CRP in the patient sample binds with the latex particles coated with specific anti-human CRP and undergoes agglutination causing change in absorbance which is dependent upon the CRP level of the patient sample. This is then quantified by comparing with a calibrator of known CRP concentration.

In the latex-enhanced immunoturbidimetry method for estimation of D-dimer ${ }^{13}$ levels in human plasma, the specific anti-D-dimer antibody that is coated on latex particles bind to D-dimer present in the sample and cause agglutination. The turbidity caused by the agglutination is detected optically by an absorbance change which is proportional to the amount of $\mathrm{D}$-dimer in the sample. The concentration is then obtained by comparison with a calibration curve of known concentrations.

Abnormalities in various parameters were defined as: serum total bilirubin (TBIL) $>2 \mathrm{mg} / \mathrm{dl}$, alanine aminotransferase (ALT) $>45 \mathrm{U} / \mathrm{l}$, aspartate aminotransferase $($ AST $)>35 \mathrm{U} / \mathrm{l}$, C-reactive protein $>6 \mathrm{mg} / \mathrm{l}$, and D-dimer $>0.5$ $\mu \mathrm{gFEU} / \mathrm{ml}$.

\section{Statistical Analysis}

Data was recorded using Microsoft Excel. Statistical analysis and graphical presentation were conducted with GraphPad Prism Version 7.0 (GraphPad Software, Inc., CA, USA). Continuous data was expressed as mean \pm standard deviation or medians with interquartile ranges as appropriate. Categorical variables of basic characteristics of COVID - 19 patients and healthy controls were compared using Fischer's exact test. Unpaired $t$ test was used to access difference in parameters between cases and controls. Throughout the text, figures, and legends the following terminology was used to show statistical significance; ${ }^{*}, \mathrm{p}=0.001,{ }^{* *} \mathrm{p}<0.0001,{ }^{* * *} \mathrm{p}=$ 0.0206 .

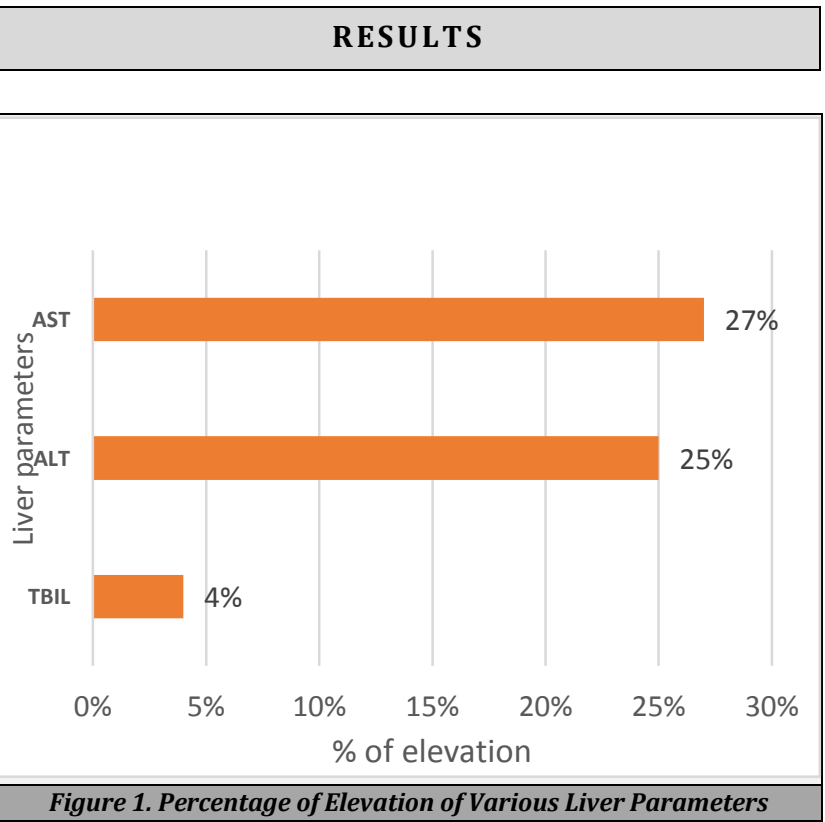

Fifty-two patients, diagnosed with COVID - 19, were included in the study, with mean age 46 years (range 20 - 75 years). They were compared with thirty age matched controls. All patients were during the second week of illness and had hypoxia with saturations less than $94 \%$, categorized as moderate and severe. Fifteen patients (29\%) had $\mathrm{SpO}_{2}<$ $90 \%$ on room air and required intensive care. There was no discrepancy of gender (male: female $=67 \%: 33 \%$ ).

Abnormal liver parameters were observed in 14 (27\%) patients, and were significantly elevated compared to healthy controls. Elevated serum total bilirubin levels were noted in 4 $\%(2 / 52)$ of patients, while serum aminotransferases, ALT \& AST elevation was observed in $25 \%$ (13/52) \& $27 \%$ (14/52) respectively, Figure 1. Statistically significant elevation of TBIL was noted in the patients of COVID - 19 compared to the healthy controls, $1.04 \pm 0.79$ vs $0.53 \pm 0.23, \mathrm{p}=0.001$. Likewise, ALT and AST also showed significant elevation compared to healthy persons. ALT $37.5 \pm 16.25$ vs $21.66 \pm$ $1.84, \mathrm{p}<0.0001$, AST $35.38 \pm 16.18$ versus $17.9 \pm 2.55, \mathrm{p}<$ 0.0001 , Table $1 \&$ Figure 2. Significant increase in the inflammatory marker CRP and D-dimer levels were also noted in cases compared to controls. CRP $20.24 \pm 21.82$ vs $2.21 \pm 0.76, \mathrm{p}<0.0001$, D-dimer $1.09 \pm 2.081$ versus $0.19 \pm 0.07, \mathrm{p}=0.0206$. CRP levels were elevated in $75 \%$ $(39 / 52)$ while D-dimer in $21 \%(11 / 52)$ of the cases.

\begin{tabular}{|c|c|c|c|c|c|}
\hline & Variables & Mean & S.D & T Value & P Value \\
\hline \multirow{2}{*}{$\begin{array}{l}\text { Serum total bilirubin (TBIL) } \\
\text { in } \mathrm{mg} / \mathrm{dl}\end{array}$} & Cases & 1.04 & 0.79 & \multirow{2}{*}{3.43} & \multirow{2}{*}{0.001} \\
\hline & Controls & 0.53 & 0.23 & & \\
\hline \multirow{2}{*}{$\begin{array}{l}\text { Alanine aminotransferase } \\
\text { (ALT) in } U / L\end{array}$} & Cases & 37.5 & 16.25 & \multirow{2}{*}{5.31} & \multirow{2}{*}{$<0.0001$} \\
\hline & Controls & 21.66 & 1.84 & & \\
\hline \multirow{2}{*}{$\begin{array}{l}\text { Aspartate aminotransferase } \\
\text { (AST) in } U / L\end{array}$} & Cases & 35.38 & 16.18 & \multirow{2}{*}{5.86} & \multirow{2}{*}{$<0.0001$} \\
\hline & Controls & 17.90 & 2.55 & & \\
\hline \multirow{2}{*}{ C-Reactive protein in mg/L } & Cases & 20.24 & 21.82 & \multirow{2}{*}{4.51} & \multirow{2}{*}{$<0.0001$} \\
\hline & Controls & 2.21 & 0.76 & & \\
\hline \multirow{2}{*}{ D-Dimer in $\mu \mathrm{gFEU} / \mathrm{ml}$} & Cases & 1.09 & 2.08 & \multirow{2}{*}{2.36} & \multirow{2}{*}{0.0206} \\
\hline & Controls & 0.19 & 0.07 & & \\
\hline Stu & $\begin{array}{l}\text { Paramet } \\
\text { ontrol an }\end{array}$ & Valu & $\begin{array}{l}\text { lean } \\
\text { ips }\end{array}$ & & aluc \\
\hline
\end{tabular}

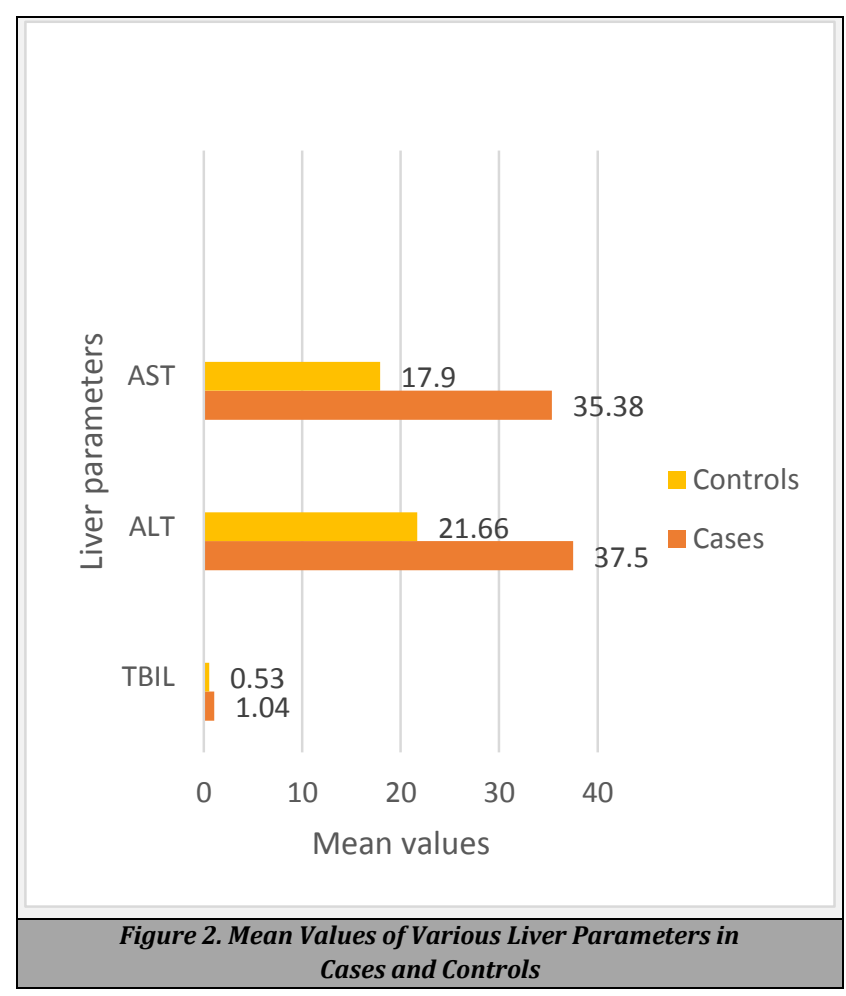


The severe patients were older compared to moderate patients, $(58.3 \pm 14.8$ vs $41.86 \pm 13.68)$. The elevation of serum total bilirubin was markedly more profound in the severe patients than the moderate ones, (TBIL $1.68 \pm 1.2$ vs $0.77 \pm 0.26, p=0.001$ ). Statistically significant increase in serum aminotransferases, ALT \& AST was noted in severe patients vs moderate patients, (ALT $52.2 \pm 21.3$ vs $31.35 \pm$ $8.5, \mathrm{p}<0.0001$, AST $49.46 \pm 21.28$ vs $29.62 \pm 8.92$, p < 0.0001), Figure 3. CRP and D-dimer values are also significantly increased in these patients correlating with the severity of the cases (CRP $40.027 \pm 28.29$ vs $12.21 \pm 11.59 \mathrm{p}<$ 0.0001 , D-dimer $2.77 \pm 2.83$ vs $0.29 \pm 0.17 \mathrm{p}<0.0001$ ).

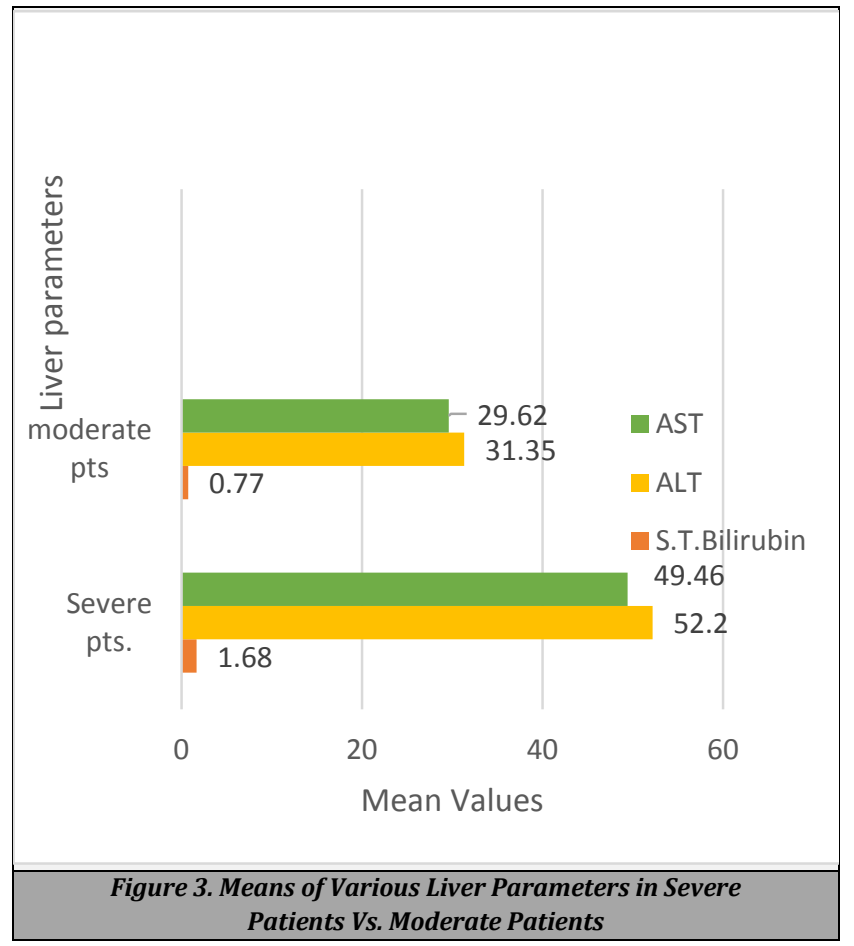

DISCUSSION

The present study substantiates the following findings: 1) COVID - 19 patients are more prone to abnormal liver parameters mostly in the form of elevated serum aminotransferases, ALT and AST 2) Liver dysfunction is present, but mostly mild, 3) Abnormalities in the liver parameters are encountered mostly in older and severely ill patients, 4) There is no gender predominance in the present study.

In agreement with previous studies, abnormalities in liver parameters were seen in $27 \%$. Table 2 illustrates the various studies reporting increase in total bilirubin and aminotransferases.

Liver dysfunction in our patients was mostly in form of serum aminotransferases, ALT and AST. This was in accord with the several studies analysing the abnormal liver biochemistries. ${ }^{8-20}$ AST is often found to exceed ALT during the course of COVID - 19. This predominance of AST is poorly elucidated, but could likely result from COVID - 19 related mitochondrial dysfunction.1,21 Systemic hypoxia in COVID 19 could also play a contributory role, as interestingly, AST elevations have been reported in other viral pneumonias such as H1N1 infection.1,22 Bertolini et al. postulated that hypoxic hepatitis can cause sharp increase in aminotransferases in the setting of respiratory failure, shock or cardiac failure, and this can ultimately lead to hepatocellular hypoxia. ${ }^{6}$ In the present study, comparable elevations for ALT and AST were noted. This was akin to the findings of Mukherjee et al., Guan et al. and Saini et al.15,19,23 Equivalent increases of AST and ALT were also demonstrated, though with mild variability, by Wang et al. Fan et al. and Chen et al. ${ }^{9,15,17}$

\begin{tabular}{|c|c|c|c|c|c|}
\hline Study & $\begin{array}{l}\text { Time of } \\
\text { Study }\end{array}$ & $\begin{array}{c}\text { Place of } \\
\text { Study }\end{array}$ & $\begin{array}{l}\text { Patients } \\
\text { Enrolled }\end{array}$ & Severe & $\begin{array}{c}\text { Details of } \\
\text { Parameters }\end{array}$ \\
\hline $\begin{array}{l}\text { Guan } \\
{\text { et } \mathrm{al}^{14}}\end{array}$ & Dec 19-Jan 20 & $\begin{array}{l}\text { Wuhan, } \\
\text { China }\end{array}$ & 1099 & 173 & $\begin{array}{l}\text { TBIL } 10.5 \% \\
\text { ALT } 21.3 \% \\
\text { AST } 22.2 \%\end{array}$ \\
\hline $\begin{array}{l}\text { Chen N } \\
\text { et al }{ }^{15}\end{array}$ & Jan 2020 & $\begin{array}{l}\text { Wuhan, } \\
\text { China }\end{array}$ & 99 & 33 & $\begin{array}{l}\text { TBIL } 18 \% \\
\text { ALT } 28 \% \\
\text { AST } 35 \%\end{array}$ \\
\hline $\begin{array}{l}\text { Fan Z } \\
\text { et al }{ }^{9}\end{array}$ & Jan-Feb 2020 & $\begin{array}{c}\text { Shanghai, } \\
\text { China }\end{array}$ & 148 & $\begin{array}{c}\text { Not } \\
\text { known }\end{array}$ & $\begin{array}{l}\text { TBIL } 6.1 \% \\
\text { ALT } 18.2 \% \\
\text { AST } 21.6 \%\end{array}$ \\
\hline $\begin{array}{l}\text { Cai } Q \\
\text { et }^{2}{ }^{8}\end{array}$ & Jan-Feb 2020 & $\begin{array}{c}\text { Shenzhen, } \\
\text { China }\end{array}$ & 417 & 91 & $\begin{array}{l}\text { TBIL } 10 \% \\
\text { ALT } 37 \% \\
\text { AST } 20 \%\end{array}$ \\
\hline $\begin{array}{l}\text { Zhang Y } \\
\text { et al }{ }^{15}\end{array}$ & Jan-Feb 2020 & $\begin{array}{l}\text { Wuhan, } \\
\text { China }\end{array}$ & 115 & 31 & $\begin{array}{c}\text { TBIL } 6.96 \% \\
\text { ALT } 9.57 \% \\
\text { AST } 14.78 \%\end{array}$ \\
\hline 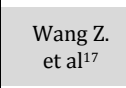 & Jan 2020 & $\begin{array}{l}\text { Wuhan, } \\
\text { China }\end{array}$ & 69 & 14 & $\begin{array}{l}\text { ALT } 33 \% \\
\text { AST } 28 \% \\
\text { CRP } 67 \%\end{array}$ \\
\hline $\begin{array}{l}\text { Xu W. } \\
\text { et al }{ }^{10}\end{array}$ & Jan-Oct 2020 & $\begin{array}{l}\text { Shanghai, } \\
\text { China }\end{array}$ & 1003 & 35 & $\begin{array}{c}\text { TBIL } 7.2 \% \\
\text { vs } 22.9 \% \\
\text { ALT } 20 \% \\
\text { vs } 12.9 \% \\
\text { AST } 42.9 \% \text { vs } \\
\& .2 \% \\
\text { Severe vs non- } \\
\text { severe }\end{array}$ \\
\hline $\begin{array}{l}\text { Saini RK. } \\
\text { et al }{ }^{18}\end{array}$ & Mar-Jun 2020 & $\begin{array}{c}\text { Chandigarh, } \\
\text { India }\end{array}$ & 170 & 33 & $\begin{array}{c}\text { TBIL } 58.5 \% \\
\text { ALT \& AST } 58.5 \\
\%\end{array}$ \\
\hline $\begin{array}{l}\text { Kalal } \\
\text { et al }{ }^{19}\end{array}$ & Mar-July 2020 & Western India & 184 & 20 & $\begin{array}{c}51.6 \% \text { abnormal } \\
\text { LFT }\end{array}$ \\
\hline $\begin{array}{l}\text { Kaushik } \\
\text { et } \text { al }^{20}\end{array}$ & Apr-May 2020 & $\begin{array}{l}\text { Uttar Pradesh, } \\
\text { India }\end{array}$ & 105 & 62 & $\begin{array}{c}59.04 \% \\
\text { abnormal LFT }\end{array}$ \\
\hline $\begin{array}{c}\text { Mukherjee } \\
\text { et } \mathrm{al}^{23}\end{array}$ & Jun-Aug 2020 & $\begin{array}{c}\text { Kolkata, } \\
\text { India }\end{array}$ & 117 & 35 & $\begin{array}{c}\text { TBIL } 0 \% \\
\text { ALT } 100 \% \\
\text { AST } 100 \%\end{array}$ \\
\hline $\begin{array}{l}\text { Present } \\
\text { study }\end{array}$ & Apr-June 2021 & $\begin{array}{l}\text { Nellore, } \\
\text { India }\end{array}$ & 52 & 15 & $\begin{array}{l}\text { TBIL } 4 \% \\
\text { ALT } 25 \% \\
\text { AST } 27 \%\end{array}$ \\
\hline \multicolumn{6}{|c|}{$\begin{array}{c}\text { Table 2. Comparison of Various Studies Analyzing Liver } \\
\text { Abnormalities in COVID-19 Patients }\end{array}$} \\
\hline
\end{tabular}

Our study also demonstrated that liver dysfunction was more notable in severe patients compared to mild and moderate patients. $8,10,16-21,23$ Saini et al. have observed that elderly and male patients with abnormal liver function were at higher risk of developing severe disease.16 Various mechanisms for COVID - 19 related liver injury have been speculated. It is well recognized that SARS-CoV-2 virus uses the angiotensin-converting enzyme (ACE2) as docking and entry receptor on host cells. ${ }^{6,24}$ Chai et al. postulate that the SARS-CoV-2 virus may bind to ACE2 on cholangiocytes leading to their dysfunction and induces a systemic inflammatory response responsible for liver injury. ${ }^{25}$ Jothimani et al. ${ }^{26}$ proposed that ischemic hepatitis, hepatic congestion related to cardiomyopathy and transaminase release due to breakdown of skeletal and cardiac muscle. On the other hand, Bangash et al. proposed that hepatic injury in COVID - 19 is due to immune interactions involving intrahepatic cytotoxic $\mathrm{T}$ cells and Kupffer cells as other respiratory viruses. ${ }^{27,28}$ Lastly, drug induced liver injury is a well-known aetiology for elevated liver parameters. The 
hepatotoxicity of remdesivir is under debate, but elevation in liver enzymes has been observed in studies between treatment and control groups. Bertolini et al. have observed that in a trial comparing remdesivir treatment for either 5 or 10 days, severe but not immediately life-threatening ALT/AST elevations were reported in $4 \%-6 \%$ of patients, and life-threatening ALT/AST elevations in $2 \%-3 \%$ of patients, necessitating treatment discontinuation. ${ }^{6} \mathrm{Xu} \mathrm{W}$ et al. have concluded in their study that COVID - 19 related liver injury is related to antiviral medication use. ${ }^{10}$ Some other differences in baseline factors like chronic liver diseases, obesity, alcohol consumption can also account for differences in liver parameters. ${ }^{10}$

Considering the mounting evidence of hyper inflammation in critically ill patients, we used a biomarker strategy to risk stratify our patients with COVID - 19, based on elevated CRP and d-dimer. CRP and D-dimer values are statistically significant in our patients correlating with the severity of the cases, in conformity with Huang et al. ${ }^{29,30}$ who have stated that CRP and D-dimer are high risk factors related to COVID - 19, of which D-dimer was the best marker. ${ }^{29}$ These markers also predict higher odds of inhospital mortality. ${ }^{30}$

\section{CONCLUSIONS}

In summary, mild liver abnormalities in the form of elevated serum aminotransferases, ALT and AST are most frequent in COVID - 19 patients suggesting mild or no liver injury. These abnormal parameters typically do not indicate liver impairment/failure and no specific treatment is required. Severe COVID - 19 patients had substantial transaminitis with abnormal TBIL, AST and ALT levels.

\section{Limitations of the Study}

Limitations of this study include its retrospective nature and inclusion of patients with COVID - 19 from a single centre. Also, the small sample size warrants for a study on a larger study group with continuous follow up and serial estimation of LFT.

Data sharing statement provided by the authors is available with the full text of this article at jemds.com.

Financial or other competing interests: None.

Disclosure forms provided by the authors are available with the full text of this article at jemds.com.

\section{REFERENCES}

[1] Marjot T, Webb GJ, Barritt AS, et al. COVID-19 and liver disease: mechanistic and clinical perspectives. Nat Rev Gastroenterol Hepatol 2021;18(5):348-64.

[2] https:www: news-medical.net/condition/coronavirusDisease-COVID-19.

[3] Vitiello A, Porta RL, D'Aiuto V, et al. The risks of liver injury in COVID-19 patients and pharmacological management to reduce or prevent the damage induced. Egyptian Liver Journal 2021;11(1):11
[4] National Institute of Diabetes and Digestive and Kidney Diseases. Acetaminophen. In: Liver Tox: Clinical and research information on drug-induced liver injury. Updated Jan 28, 2016.

[5] Bertolini A, Van de Peppel IP, Bodewes FAJA, et al. Abnormal liver finction tests in patients with COVID-19: relevance and potential pathogenesis. Hepatology 2020;72(5):1864-72.

[6] Mahamid M, Mader R, Safadi R. Hepatotoxicity of tocilizumab and anakinra in rheumatoid arthritis: management decisions. Clin Pharmacol 20113:39-43.

[7] Hundt MA, Deng Y, Ciarleglio MM, et al. Abnormal liver tests in COVID-19: a retrospective observational Cohort study of 1827 patients in a major U.S. hospital network. Hepatology 2020;72(4):1169-76.

[8] Cai Q, Huang D, Yu H, et al. COVID-19: Abnormal liver function tests. J Hepatol 2020;73(3):566-574.

[9] Fan Y, Chen L, Li J, et al. Clinical features of COVID-19related liver functional abnormality. Clin Gastroenterol Hepatol 2020;18(7):1561-1566

[10] Xu W, Huang C, Fei L, et al. Dynamic changes in liver function tests and their correlation with illness severity nd mortality in patients with COVID-19: a retrospective cohort study. Clin Interv Aging 2021;16:675-85.

[11] Tietz NW. Textbook of clinical chemistry. Philadelphia: W.B. Saunders 1986: p. 1388.

[12] OtsujiS, Shibata H, Umeda $M$, et al. Turbidimetric immunoassay of serum C-reactive protein. Clin Chem 1982;28(10):2121-4.

[13] Rylatt DB, Blake AS, Cottis LE, et al. an immunoassay for human D-dimer using monoclonal antibodies. Thromb Res 1986;31(6):767-78.

[14] Guan WJ, Ni ZY, HU Y, et al. Clinical characteristics of coronavirus disease 2019 in China. N Engl J Med 2020;382:1708-20.

[15] Chen N, Zhou M, Dong X, et al. Epidemiological and clinical characteristics of 99 cases of 2019 novel coronavirus pneumonia in Wuhan, China: A descriptive study. Lancet 2020;395(10223):507-13.

[16] Zhang Y, Zheng L, Liu L, et al. Liver impairment in COVID19 patients a retrospective analysis of 115 cases from a single centre in Wuhan city, China. Liver Int 2020;40(9):2095-103.

[17] Wang Z, Yang B, Li Q, et al. Clinical features of 69 cases with coronavirus disease 2019 in Wuhan, China. Clin Infect Dis 2020;71(15):769-77.

[18] Saini RK, Saini N, Ram S, et al. COVID-19 associated variations in liver parameters: a retrospective study. Postgrad Med J 2020.

[19] Kalal CR, Joshi H, Kumar V, et al. Clinical significance of liver function abnormality in patients with COVID-19: a Single-center experience from Western India. J Clin Transl Hepatol 2021;9(6):878-88.

[20] Kaushik A, Wani SN, Baba MA, et al. Prevalence of abnormal liver function tests in COVID-19 patients at a tertiary care centre. J Assoc Physicians India 2020;68(8):73-5.

[21] Gordon D, Jang GM, Bouhaddaou M, et al. A SARS CoV-2 protein interaction map reveals targets for drug repurposing. Nature 2020;583(7816):459-68.

[22] Papic N, Pangercic A, Vargovic M, et al. Liver involvement during influenza infection: perspective on the 2009 
influenza pandemic. Influenza and Other Respir Viruses 2012;6(3):e2-5.

[23] Mukherjee K, Banerjee A, Bhattacharjee D, et al. Liver function status in COVID-19: an Indian perspective. J Assoc Physicians India 2021;69(2):19-21.

[24] Zhou P, Yang XL, Wang XG, et al. A pneumonia outbreak associated with a new coronavirus of probable bat origin. Nature 2020;579:270-3.

[25] Chai X, Hu I, Zhang Y, et al. Specific ACE2 expression in cholangiocytes may cause liver damage after 2019-nCo Vinfection. bio-Rxiv 2020. doi: https://doi.org/10.1101/2020.02.03.931766

[26] Jothimani D, Venugopal R, Abedin MF, et al. COVID-19 and the liver. J Hepatol 2020;73(5):1231-40.
[27] Bangash MN, Patel J, Parekh D. COVID-19 and the liver: little cause for concern. Lancet Gastroenterol Hepatol 2020;5(6):529-530.

[28] Adams DH, Hubscher SG. Systemic viral infections and collateral damage in the liver Am J Pathol 2006;168(4):1057-9.

[29] Huang I, Pranata R, Lim MA, et al. C-reactive protein, procalcitonin, D-dimer, and ferritin in severe coronavirus disease-2019: a meta-analysis. Ther Adv Respir Dis 2020;14:1753466620937175.

[30] Ullah W, Thalambedu N, Haq S, et al. Predictability of CPR and D-dimer levels for in-hospital outcomes and mortality of COVID-19. J Community Hosp Intern Med Perspect 2020; 10(5):402-8. 